\title{
EVALUASI PENERIMAAN APLIKASI MODUL PENERIMAAN NEGARA GENERASI KEDUA (MPN G2) DENGAN PENDEKATAN MODEL INTEGRASI TRUST-TAM-TPB DARI PERSPEKTIF PENGGUNA
}

Galang Pujo Setyanto

Direktorat Jenderal Perbendaharaan

Alamat Korespondensi: pudjo.kdr@gmail.com

\begin{abstract}
The Second Generation Government Receipt System (MPN G2) is one of government effort to manage cash and to improve citizen contribution service. However, the implementation took time for adjustment in Jakarta before the systemused by most of its citizen. The use of e-banking which is one of key advantage in MPN G2 waslow. This paper evaluates MPN G2 by usingacceptance factors on the Trust-TAM-TPB model. It shows that MPN G2 needs to be improved. The billing needs repairment to enhance perceived usefulness and perceived ease of use. Additionally, the E-banking facility needs repairment to enhace perceived usefulness, perceived ease of use, and trust.
\end{abstract}

KATA KUNCI:

Evaluasi, MPN G2.

\begin{abstract}
ABSTRAK
Sistem Modul Penerimaan Negara Generasi Kedua (MPN G2) merupakan salah satu upaya dan inovasi pemerintah dalam rangka manajemen kas dan memperbaiki pelayanan kepada masyarakat. Namun faktanya, implementasi MPN G2 di Provinsi DKI Jakarta ternyata membutuhkan waktu yang cukup lama sebelum akhirnya dipergunakan oleh sebagian besar masyarakat. Selain itu penggunaan fasilitas e-banking yang seharusnya menjadi keunggulan dari sistem MPN G2, ternyata masih rendah. Paper ini mengevaluasi sistem MPN G2 menggunakan faktor-faktor penerimaan pada model -Trust-TAMTPB. Hasil evaluasi menunjukkan bahwa diperlukan perbaikan-perbaikan terkait sistem tersebut. Pembuatan billing sebagai salah satu fasilitas yang diberikan MPN G2 memerlukan perbaikan untuk meningkatkan persepsi kegunaan dan persepsi kemudahannya. Sedangkan fasilitas pembayaran e-banking memerlukan perbaikan untuk meningkatkan persepsi kegunaan, persepsi kemudahan, dan kepercayaan fasilitas tersebut.
\end{abstract}

KLASIFIKASI JEL:

G38, H20, 


\section{PENDAHULUAN}

\subsection{Latar Belakang}

Salah satu usaha Kementerian Keuangan untuk meningkatkan capaian target penerimaan negara adalah dengan membangun sistem penerimaan negara. Pengembangan Modul Penerimaan Negara Generasi Pertama (MPN G1) merupakan bentuk upaya Kementerian Keuangan dalam membangun sistem penerimaan negara yang pertama. Subkhani (2016) menyatakanbahwa layanan menggunakan sistem MPN G1 dirasa masih banyak kekurangan, diantara yang paling menonjol adalah terbatasnya layanan yang disediakan terkait jenis transaksi pembayaran, waktu, dan tempat layanan.Upaya penyempurnaan sistem MPN G1 ditandai dengan diterbitkannya Peraturan Menteri Keuangan Nomor PMK-32/PMK.05/2014 tentang Sistem Penerimaan Negara secara Elektronik. PMK tersebut menjadi dasar hukum digunakannya Modul Penerimaan Negara Generasi Kedua (MPN G2). Sistem MPN G2 berperan dalam menghilangkan keterbatasan tempat dan waktu dalam proses pembayaran sehingga mempercepat penguasaan kas dalam rangka optimalisasi kas. Iskandar (2017) menjelaskan bahwa tujuan pengelolaan kas negara adalah untuk memastikan adanya jumlah uang yang tepat pada tempat dan waktu yang tepat pula, sehingga mampu memenuhi kewajiban dengan cara yang efektif. Tujuan tersebut dapat dicapai dengan mempercepat penguasaan kas.

Salah satu tujuan utama penggunaan MPN G2 adalah perubahan sistem pembayaran secara manual ke sistem elektronik yang lebih fleksibel. Penggunaan channel pembayaran dengan teller merupakan sistem pembayaran yang melekat pada sistem MPN G1, dimana masyarakat mengisi secara manual dokumen pembayaran (Surat Setoran Pajak/SSP, Surat Setoran Bukan Pajak/SSBP, Surat Setoran Pengembalian Belanja/SSPB, atau Surat Setoran Pabeanan, Cukai, dan Pajak/SSPCP), kemudian membayar melalui teller pada bank persepsi yang ditunjuk pemerintah. Keunggulan MPN G2 terkait fleksibilitas waktu dan tempat yang direpresentasikan dengan penggunaan fasilitas ebanking (ATM, internetbanking, dan mobilebanking) justru tidak dimanfaatkan. Sejalan dengan hal tersebut, salah satu tujuan manajemen kas dengan sistem MPN G2 yaitu mempercepat penguasaan kas oleh negara menjadi tidak tercapai.

Untuk menguji efektivitas operasi MPN, paper ini menggunakan sampel responden di DKI Jakarta. DKI Jakarta sebagai ibukota negara dan jantung perekonomian di Indonesia adalah provinsi dengan tingkat penerimaan negara yang paling tinggi jika dibandingkan dengan provinsi-provinsi lain di Indonesia. Pada tahun 2016, Provinsi DKI Jakarta membukukan penerimaan negara sebesar Rp712 triliun (dashboard MPN G2, diakses tanggal 30
September 2017).Nilai ini hampir lima puluh persen dari total penerimaan APBNatau sebesar Rp 1.664 triliun (LKPP audited tahun 2016).Pengelolaan penerimaan tersebut dengan menggunakan sistem MPN G2 tersebut ternyatamenemui beberapa hambatan. Hal tersebut terlihat dari lambatnya penggunaan MPN G2 oleh masyarakat di Provinsi DKI Jakarta. Penggunaan MPN G2 baru meningkat tajam ketika sistem yang lama mulai dikurangi dan dihentikan pelayanannya. Selain itu apabila dilihat lebih detil lagi terkait pemilihan channel (kanal) pembayaran dalam penggunaan MPN G2, terlihat bahwa penggunaan channel pembayaran dengan teller jumlahnya masih dominan (di atas 70 persen), baik pada tahun 2014, 2015, dan 2016. Pada tahun 2014 penggunaan pembayaran dengan teller adalah sebesar 73 persen, pada tahun 2015 sebesar 88 persen, dan pada tahun 2016 sebesar 70 persen.

\section{Grafik 1. Transaksi MPN G2 Lingkup DKI Jakarta}

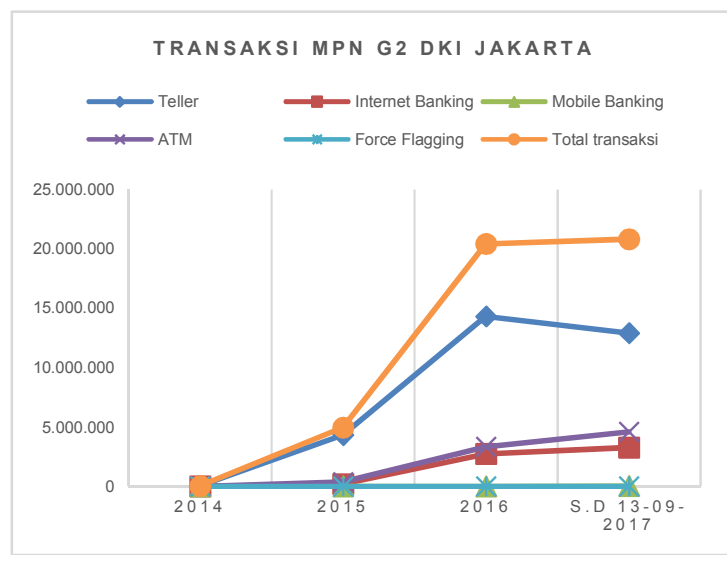

Sumber: Diolah penulis dari data KPPN Khusus Penerimaan

Berdasarkan uraian di atas dapat diketahui bahwa minat sebagian besar masyarakat DKI Jakarta untuk memanfaatkan fasilitas yang disediakan sistem MPN G2 baru meningkat tajam ketika layanan sistem MPN G1 mulai dikurangi dan dihentikan oleh pemerintah. Pemanfaatan sistem MPN G2 itupun sebagian besar hanya berpindah dari pembuatan dokumen pembayaran secara manual ke pembuatan dokumen pembayaran secara online (billing). Selebihnya sebagian besar dari mereka masih memilih membayar dengan sistem yang lama yaitu langsung membayar ke teller bank daripada menggunakan channel-channel pembayaran lain yang lebih fleksibel baik dari sisi waktu dan tempat. Minat masyarakat untuk menggunakan fasilitas e-banking dalam pembayaran penerimaan negara masih rendah jika dibandingkan dengan pembayaran dengan menggunakan teller bank.

Kementerian Keuangan perlumelakukan evaluasi terhadap sistem yang telah berjalan, dalam 
hal ini MPN G2, untuk mengidentifikasi faktorfaktor yang dapat mempengaruhi penerimaan dan penggunaan sistem tersebut, serta permasalahan yang terjadi di dalamnya. Hal ini dimaksudkan agar hasil evaluasi dapat dijadikan bahan masukan, sehingga MPN G2 dapat dimaksimalkan penggunaannya dan dapat memberikan manfaat, baik untuk pemerintah maupun untuk masyarakat.

Wu dan Chen (2005) menawarkan model yang komprehensif dari model penelitian-penelitian yang lain untuk mengukur penerimaan sistem karena menggabungkan beberapa model sekaligus. Model tersebut dipakai untuk mengevaluasi penerimaan sistem MPN G2. Penelitian yang dilakukan Wu dan Chen (2005) merupakan penelitian yang fokus kepada penerimaan e-service berupa onlinetax di Taiwan. Wu dan Chen (2005) mencoba mencari faktor-faktor yang berpengaruh terhadap rendahnya penggunaan online-tax di Taiwan dengan menggabungkan model-model yang sering digunakan untuk meneliti penerimaan sistem. Dari hasil penelitiannya, Wu dan Chen (2005) menyimpulkan bahwa Trust, Perceived Usefulness, dan Perceived Ease of Use berperan dalam menentukan intention to use sistem tersebut. Pendekatan model integrasi Trust-TAM-TPB digunakan karena model tersebut dirasa dapat memberikan hasil yang lebih komprehensif karena menggabungkan beberapa model sekaligus.

Paper ini akan mengevaluasi terhadap penerimaan dan penggunaan MPN G2 khususnya terhadap dua fasilitas utama MPN G2 yaitu fasilitas billing dan fasilitas e-banking dimana kedua fasilitas tersebut seharusnya menjadi keunggulan dari sistem MPN G2 akan tetapi penggunaan fasilitas tersebut cenderung masih sedikit.

\section{KERANGKA TEORI}

\subsection{Technology Acceptance Model (TAM)}

Technology Acceptance Model (TAM) merupakan pengembangan dari Theory of Reasoned Action yang dicetuskan oleh Fishbein dan Ajzen (1975). Menurut Davis dalam Wu dan Chen (2005), TAM didesain untuk memodelkan penerimaan pengguna terhadap teknologi informasi.Model TAM menggambarkan bahwa penggunaan sistem ditentukan oleh niat untuk menggunakan (Behaviour Intention to Use). Keinginan untuk menggunakan dipengaruhi oleh sikap pengguna akan sistem (Attitude Toward Using) dan persepsi kebermanfaatan (Perceived Usefullness). Attitude dan Perceived Usefullness (PU) dipengaruhi oleh persepsi kemudahan penggunaan (perceived ease of use/PEOU). Wu dan Chen (2005) mengartikan Perceived usefulness dan Perceived ease of use sebagai “ $P U$, reflecting a person's salient belief in using the technology,will be helpful in improving performance. PEOU, explaining a person's salient beliefs in using the technology, will be free of any effort."Subkhani (2016) mengutip pernyataan Davis bahwa "beberapa indikator perceived usefulness dari penggunaan suatu sistem informasi, yaitu work more quickly, job performance, increase productivity, effectiveness, makes job easier, dan useful."

\subsection{Theory Planned Behaviour (TPB)}

Menurut Wu dan Chen (2005),TPB telah terbukti sukses dalam memprediksi dan menjelaskan perilaku manusia terkait dengan teknologi informasi. Menurut Theory Planned Behaviour, tindakan nyata manusia dalam melakukan berbagai aktivitas dipengaruhi oleh keinginan (Behaviour Intention) orang tersebut. Keinginan berperilaku orang ditentukan oleh beberapa faktor antara lain Attitude, Subjective Norm, dan Perceived Behavior Control.

\subsection{Model Penerimaan Integrasi Trust-TAM- TPB}

Wu dan Chen (2005) melakukan penelitian tentang penerimaan sistem onlinetax di Taiwan. Mereka mengembangkan model sendiri yang merupakan gabungan dari beberapa model yang telah dikembangkan oleh peneliti-peneliti sebelumnya. Model tersebut antara lain adalah model Trust, model Technology Acceptance Model, dan model Theory of Planned Behaviour. Menurut Wu dan Chen (2005) integrasi Trust dan TAM model dengan TPB, termasuk Subjective Norm dan Perceived Behaviour Control seharusnya dapat memberikan hasil yang lebih komprehensif dalam memeriksa penerimaan sistem.

Menurut Luhmann dalam Wu dan Chen (2005) Trust sering kali dilihat sebagai mekanisme untuk mengurangi kerumitan sosial dan persepsi risiko dari transaksi melalui peningkatan ekspektasi akan hasil yang positif dan persepsi kepastian ekspektasi perilaku pihak yang terkait dalam transaksi.

Trust dan TAM saling berhubungan satu dengan yang lain. Trust adalah pembentuk dari variabel Perceived Usefulness, khususnya pada transaksi yang terjadi secara online. Trust akan membuat konsumen menjadi lebih merasakan manfaat dari layanan yang disediakan oleh penyedia. Pavlou dalam $\mathrm{Wu}$ dan Chen (2005) mengatakan bahwa Trust memberikan efek yang positif pada Perceived usefulness karena menjadikan konsumer lebih mudah terpengaruh oleh penyedia layanan bahwa mereka akan mendapat keuntungan. Di sisi lain, Perceived ease of use mempunyai efek yang positif terhadap Trust. Menurut Ganesan dan Gefen dalam Wu dan Chen (2005) Perceived ease of use bisa meningkatkan impresi yang menyenangkan pada implementasi sistem yang pertama kali, sehingga konsumen bersedia untuk melakukan investasi dan komitmen.

Trust dan TPB saling berhubungan satu dengan yang lain. Trust merupakan pembentuk 
variabel-variabel yang ada pada TPB (Attitude, Subjective Norm, dan Perceived Behavior Control). Trust merupakan pembentuk dari Attitude dimana menurut Luhmann, Lewis, dan Weigert dalam $\mathrm{Wu}$ dan Chen (2005) Trust pasti meningkatkan kepastian dalam hubungan bisnis dan menentukan kualitas transaksi antara penjual dan pembeli, demikian juga ekspektasi hasil yang diterima atau dengan kata lain meningkatkan attitude toward behaviour. Menurut Pavlou dalam $\mathrm{Wu}$ dan Chen (2005)Trust dapat meningkatkan Perceived Behavior Control pada transaksi online karena transaksi antara konsumen dan penyedia layanan menjadi lebih dapat diperkirakan. Trust memberikan perasaan yang menyenangkan dan kondisi yang menyenangkan pula. Menurut Wu dan Chen (2005) pada dasarnya dapat diprediksi bahwa Trust terhadap penggunaan sistem informasi berperan dalam menentukan Subjective Norm. Trust kepada penyedia layanan tentang reputasi, nama besar, dan pelayan berpengaruh positif terhadap Subjective Norm dalam transaksi secara online.

\subsection{Persepsi}

Kotler (2000) menjelaskan bahwa persepsi adalah proses bagaimana seseorang menyeleksi, mengatur, dan mengintreprestasikan masukanmasukan informasi untuk menciptakan gambaran keseluruhan yang berarti. Hal tersebut menunjukkan bahwa persepsi pandangan seseorang terhadap sesuatu. Robbins (2003) menambahkan bahwa persepsi dengan kaitannya dengan lingkungan, yaitu sebagai proses di mana individu-individu mengorganisasikan dan menafsirkan kesan indera mereka kepada lingkungan mereka.

\subsection{Sikap}

Tankard (2001) mendefinisikan sikap sebagai tendensi manusia terhadap sesuatu. Sedangkan menurut Bruno dalam Syah (2005) sikap atau attitude adalah kecenderungan yang relatif menetap untuk bereaksi dengan cara baik atau buruk terhadap barang atau barang tertentu. Dari pengertian di atas dapat disimpulkan bahwa sikap adalah kecenderungan untuk menilai suatu objek yang sifatnya positif atau negatif. Sikap positif diperlihatkan dengan setuju, menerima, mendekati, sedangkan sikap negatif ditunjukkan dengan tidak setuju, menjauhi, dan menolak.

\subsection{Modul Penerimaan Negara Generasi Kedua (MPN G2)}

Sesuai dengan Pasal 7 ayat (2) huruf d UndangUndang Nomor 1 Tahun 2004 tentang Perbendaharaan Negara, Menteri Keuangan selaku Bendahara Umum Negara berwenang menetapkan sistem penerimaan dan pengeluaran kas negara. Dalam Peraturan Menteri Keuangan Nomor 32/PMK.05/2014 tentang Sistem Penerimaan Negara secara Elektronik disebutkan bahwa dalam rangka menyempurnakan penatausahaan dan pertanggungjawaban penerimaan negara, pemerintah perlu menerapkan sistem penerimaan negara secara elektronik dengan memanfaatkan sistem teknologi informasi. Berdasarkan dua landasan hukum tersebut, diciptakanlah Modul Penerimaan Negara Generasi Kedua (MPN G2). MPN G2 adalah sistem penerimaan negara yang menggunakan surat setoran secara elektronik, yaitu surat setoran yang dibuat berdasarkan billing.

MPN G2 diciptakan untuk memperbaiki dan menyempurnakan kekurangan yang terdapat pada penatausahaan dan pertanggungjawaban penerimaan negara dari sistem MPN sebelumnya (MPN G1) (Subkhani 2016). Sistem penerimaan negara yang lama (MPN G1) masih dilakukan secara manual, sehingga masih mengakibatkan beberapa masalah. Masalah di sisi pengelolaan penerimaan yaitu tingginya perbedaan pada saat rekonsiliasi penerimaan negara karena kesalahan manusia pada saat input data penerimaan. Masalah di sisi pengguna (masyarakat) yaitu pembayaran penerimaan negara hanya bisa dilakukan melalui loket penerimaan di bank/pos persepsi di mana jam layanannya terbatas hari dan jam kerja. Selain itu MPN G1 masih menggunakan sistem single currency, jadi pembayaran hanya bisa dilakukan dengan menggunakan mata uang rupiah.

Pengembangan MPN G2 diarahkan untuk memberikan fleksibilitas yang lebih tinggi bagi wajib pajak/bayar. Sistem MPN G2 menggunakan aplikasi billing sistem sehingga wajib pajak/bayar dapat melakukan pengisian billing secara mandiri melalui portal yang disediakan secara online. Pembayaran atas billing dapat dilakukan melalui payment channel secara elektronik (ATM, e-banking, debit/kredit card, dan mobile banking).

\subsection{Penelitian Sebelumnya}

Penelitian tentang penerimaan sistem menggunakan model integrasi Trust-TAM-TPB baru dilakukan oleh $\mathrm{Wu}$ dan Chen (2005). Penelitian yang dilakukan $\mathrm{Wu}$ dan Chen merupakan penelitian kuantitatif yang fokus kepada penerimaan $e$-service berupa online tax di Taiwan. Penelitian tersebut berjudul An Extension of Trust and TAM Model with TPB in the Initial Adoption of On-Line Tax: An Empirical Study. Wu dan Chen mencoba mencari variabel yang berpengaruh terhadap rendahnya penggunaan online-tax di Taiwan dengan menggabungkan model-model yang sering digunakan untuk meneliti penerimaan sistem. Variabel yang digunakan dalam penelitian tersebut adalah Trust, Perceived usefulness, Perceived ease of use, Attitude, Subjective norm, Perceived Behaviour Control, dan Intention To Use. Dari hasil penelitiannya, Wu dan Chen menyimpulkan bahwa Trust, Perceived usefulness, danPerceived ease of use berperan dalam menentukan intention to use sistem tersebut. Setiap variabel mempengaruhi Intention 
To Use melalui beberapa mediator seperti Attitude, Perceived Behavioral Control, danSubjective Norm. $\mathrm{Wu}$ dan Chen (2005) menjelaskan bahwa "This means that to effectively attract citizens to use on-line tax, the design of the on-line tax needs to carefully pay attention to both aspect."

Subkhani (2016) melakukan penelitian tentang penggunaan billing online di kantor vertikal Direktorat Jenderal Bea Cukai yang merupakan salah satu biller pada sistem MPN G2. Penelitian tersebut berjudul Evaluasi terhadap Penggunaan Sistem Billing Online DJBC dengan Pendekatan TAM (Studi Kasus di KPU Bea dan Cukai Tipe A Tanjung Priok). Pada penelitian tersebut Subkhani (2016) mencari hubungan antara beberapa variabel yang terangkum dalam model TAM. Variabel-variabel yang digunakan antara lain: Perceived Usefulness, Perceived Ease of Use, Self-Efficacy, Perceived Credibility, Perceived Services and Information Quality, Adoption Intention, dan Usage Behaviour. Subkhani (2016) menyimpulkan bahwa dalam penggunaan sistem billing online $\mathrm{DJBC}$, variabel Adoption Intention berpengaruh signifikan terhadap Usage Behavior, variabel Perceived Usefulness dan Self-Efficacy berpengaruh signifikan terhadap Adoption Intention, dan variabel Perceived Ease of Use berpengaruh signifikan terhadap Perceived Usefulness. Sedangkan variabel Perceived Ease of Use, Perceived Credibility, dan Perceived Service and Information Quality tidak berpengaruh terhadap Adoption Intention.

\section{METODE PENELITIAN}

Pada penelitian ini, penulis menggunakan metode penelitian kualitatif untuk melihat bagaimana penerimaan user terhadap MPN G2 dan faktor-faktor terkait penerimaan MPN G2. Pendekatan kualitatif adalah metode-metode untuk mengeksplorasi dan memahami makna yang oleh sejumlah individu atau sekelompok orang dianggap berasal dari masalah sosial atau kemanusiaan (Creswell, 2016). Menurut Omar (2016), studi kualitatif menjanjikan informasi yang lebih banyak dan lebih jelas terkait penerimaan sistem. Sejalan dengan hal tersebut, Renaund dkk (2008) mengatakan bahwa: "it is clear that ease of use can not really be self reported, it is far more enlightening to observe users making use of a product. Therefore it is better to ask end user about the features they use most often." Lee dkk (2003) menambahkan bahwa "the qualitative study using the TAM model is more useful alternative to determine richer information with small number of research participants". Penelitian ini menggunakan pendekatan fenomologi karena penelitian ini terfokus pada bagaimana mendeskripsikan secara lebih detail mengenai persepsi dan niat user terhadap penerimaan dan penggunaan aplikasi MPN G2 berdasarkan pengalaman mereka.

Pada penelitian ini cara pengumpulan data dilakukan dengan jalan wawancara dan dokumentasi berupa pencarian literatur yang sesuai dengan penelitian ini. Pemilihan pengumpulan data pada penelitian ini terkait dengan rancangan penelitian yang telah dipilih yaitu fenomologi di mana pengumpulan data yang sesuai dengan strategi penelitian tersebut adalah wawancara. User MPN G2 di lingkup Provinsi DKI Jakarta yang akan dijadikan narasumber dalam penelitian ini akan terdiri dari tiga jenis antara lain user untuk pembayaran pajak, user pembayaran PNBP, dan user pembayaran bea dan cukai. Karena keterbatasan waktu dan tenaga maka akan dipilih narasumber dari beberapa kantor vertikal Kementerian Keuangan di wilayah provinsi DKI Jakarta. Total keseluruhan narasumber yang digunakan dalam penelitian ini berjumlah 32 orang.

Teknik analisis data pada penelitian ini akan menggunakan metode yang dikembangkan oleh Creswell. Pada penelitian ini, data mentah yang didapatkan dari narasumber melalui wawancara akan dianalisis, didiskusikan, dan diterjemahkan ke dalam framework model integrasi Trust-TAMTPB.Menurut Creswell (2016) dasar proses analisis data kualitatif adalah sebagai berikut:

a. mengolah dan mempersiapkan data untuk dianalisis. Langkah ini melibatkan transkripsi wawancara, men-scanning materi, mengetik data lapangan, atau memilah-milah dan menyusun data tersebut ke dalam jenis-jenis yang berbeda tergantung pada sumber informasi;

b. membaca keseluruhan data. Langkah pertama adalah membangun general sense atas informasi yang diperoleh dan merefleksikan maknanya secara keseluruhan;

c. melakukan coding secara manual atas transkrip yang ada. Hal ini mengacu pada mengorganisasikan materi ke dalam potongan atau segmen teks ke dalam kata atau frase sebelum memberikan makna;

d. mengategorikan dan mengembangkan tema untuk proses analisis. Tema yang telah diidentifikasi muncul sebagai temuan utama dan digunakan untuk membuat judul di bagian hasil;

e. melakukan deskripsi pada tema; dan

f. menafsirkan makna data dan menanyakan pelajaran apa dapat dipelajari dan kesimpulan diambil dari data yang telah ditafsirkan.

Hasil yang diperoleh dari hasil analisis akan didiskusikan dan dibandingkan dengan literaturliteratur dan penelitian sebelumnya. 


\section{HASIL PENELITIAN}

\subsection{Evaluasi Fasilitas Billing}

4.1.1.Evaluasi persepsi kegunaan (Perceived usefulness) fasilitas billing

Secara umum, persepsi yang positif akan kegunaan sistem (Perceived usefulness) MPN G2 adalah bukti bahwa penggunaan MPN G2 meningkatkan kinerja pekerjaan mereka dalam melakukan pembayaran pajak, bea cukai, maupun penerimaan bukan pajak. Walaupun begitu, beberapa user merasa kesulitan untuk menyelesaikan tugas mereka dengan cepat pada saat jaringan atau server billing mengalami gangguan. Hampir 90 persen narasumber yang diwawancarai mengalami permasalahan jaringan dalam penggunaan billing. Liao \& Cheung (2002) mengatakan bahwa "This proposition indicates that customers find it important that the service is fast and easy, and that if slow, the perceived usefulness of the service would be much lower." Menurut beberapa narasumber, gangguan tersebut biasanya terjadi pada saat mereka sedang membutuhkan waktu yang cepat untuk melakukan pembayaran. Khusus untuk pembuatan billing untuk pajak impor barang, narasumber merasa proses perbaikan yang lama atas billing yang sudah terlanjur diterbitkan. Mereka tidak bisa membuat billing yang baru sampai dengan lima hari berikutnya ketika billing yang lama telah batal secara otomatis.

Yang kedua adalah permasalahan dimana sering terjadi perbedaan data antara server MPN G2 dengan data pembayaran di bank sehingga user yang statusnya sudah melakukan pembayaran di sistem perbankan, tercatat belum melakukan pembayaran di sistem MPN G2. Sekitar 12,5 persen narasumber yang kami wawancarai mengalami permasalahan ini. Hal tersebut sejalan dengan pernyataan Davis dkk (1989) bahwa "If one of them produces an objectively more accurate... it would likely be seen as more useful". Perbaikan atas kejadian tersebut memakan waktu dan biaya yang lumayan. Walaupun kejadian itu tidak berlangsung terus menerus, akan tetapi gangguan sistem tersebut mempunyai pengaruh besar dalam proses pembayaran pajak, bea cukai, dan penerimaan bukan pajak. Cepat tidaknya penyelesaian pembayaran dalam hal ini pembuatan billing, akan berpengaruh terhadap keuntungan dan kerugian finansial yang dialami oleh user. Misalnya untuk pembayaran pajak impor barang dengan menggunakan mata uang asing, dimana keterlambatan pembayaran akan mengakibatkan kerugian selisih nilai kurs apabila sudah berbeda hari pembayaran. Kemudian apabila pembayaran pajak mengalami keterlambatan, maka user juga akan terkena sanksi atau hukuman dari institusi pajak. Dari wawancara yang kami lakukan, sekitar
18 persen narasumber yang membayar pajak impor barang pernah mengalami kesulitan tersebut.

4.1.2. Evaluasi persepsi kemudahan (Perceived ease of use) fasilitas billing

Hasil wawancara yang telah dilakukan menunjukkan bahwa sekitar 93 persen narasumber memberikan respon yang positif terhadap kemudahan penggunaan MPN G2 khususnya dalam pembuatan billing. Mereka hanya cukup memilih form isian online yang telah disediakan dan menuliskan jumlah pembayarannya, sehingga tidak ada kesulitan yang berarti. Walaupun penggunaan MPN G2 khususnya penggunaan fasilitas pembuatan billing mudah dan jelas untuk dimengerti, hasil dari wawancara juga mengindikasikan bahwa beberapa narasumber mengalami kesulitan dalam menggunakan fasilitas billing, yaitu:

a. Kesulitan untuk mengakses atau masuk ke halaman pembuatan billing ketika server atau jaringan sedang sibuk atau bermasalah.

Kemudahan penggunaan sistem MPN G2 khususnya fasilitas pembuatan billing akan menurun ketika kondisi server billing sedang bermasalah terutama pada jam-jam sibuk. Mereka merasa kesulitan untuk mengakses atau masuk ke halaman pembuatan billing dan kalaupun sudah masuk, mereka tidak akan bisa membuat billing karena sering kali $\log$ out sendiri, sehingga berkali-kali user harus $\log$ in ulang. Hampir 90 persen narasumber yang diwawancarai pernah mengalami kesulitan ini. Lin and Lu (2000) mengatakan bahwa "similarly reported that higher information accessibility brings about higher use of information and higher perception of ease of use".

b. Terbatasnya pemberian keterangan billing atau pembayaran.

Kesulitan kedua yang dialami oleh beberapa narasumber terkait pemberian keterangan pembayaran dalam pembuatan billing. Pemberian keterangan pada pembuatan billing secara online tidak seleluasa pemberian keterangan pada sistem secara manual. Sistem billing membatasi jumlah karakter yang bisa diinput untuk pemberian keterangan peruntukan pembayaran, bahkan pada pembuatan billing untuk pajak tidak disediakan kolom untuk memberikan keterangan peruntukan pembayaran. Sekitar 27 persen narasumber yang menggunakan billing untuk pembayaran PNBP mengalami kesulitan ini. Padahal user memerlukan keterangan pembayaran untuk memperjelas dan membedakan pembayaran yang mereka lakukan. Sekitar hal tersebut senada dengan pernyataan Davis dkk (1989) bahwa "Many system features such as menus, icons, mice, and 
touch screens are spesifically intended to enhance usability. The impact of system feature impact on EOU has been documented."

c. Proses monitoring yang sulit dan membutuhkan usaha ekstra atas billing yang sudah dibuat atau sudah dibayar.

Kesulitan yang ketiga adalah dalam hal monitoring billing yang sudah dibuat dan yang sudah dibayar ke bank. Pada sistem yang sekarang mereka membutuhkan usaha lebih untuk melakukan monitoring karena desain menu monitoring yang susah untuk digunakan. Sekitar 9 persen narasumber yang menggunakan billing untuk pembayaran PNBP mengalami kesulitan ini. Padahal fungsi monitoring pembayaran merupakan hal yang penting bagi user untuk mengontrol dan mengawasi pembayaran yang telah mereka lakukan. Hal tersebut berlawanan dengan pernyataan Davis dkk (1989) bahwa "Many system features such as menus, icons, mice, and touch screens are spesifically intended to enhance usability... The impact of system feature impact on EOU has been documented."

d. Pengguna baru akan kesulitan menggunakan aplikasi billing karena kurangnya petunjuk atau tutorial penggunaan.

Kesulitan yang terakhir adalah untuk pengguna yang baru berhadapan dengan MPN G2 dalam hal ini fasilitas pembuatan billing, akan kesulitan untuk menggunakan aplikasi tersebut karena mereka masih belum tahu fungsi dari setiap menu yang disediakan dan bagaimana langkah-langkah untuk menggunakan aplikasi tersebut. Kesulitan tersebut terjadi karena tidak ada tutorial atau langkah-langkah penggunaan dari aplikasi tersebut, sehingga mau tidak mau mereka harus mencari referensi pada sumber yang lain. Sekitar 40 persen narasumber yang diwawancarai mengalami kesulitan ini. Menurut Davis dkk (1989) bahwa "Training, documentation, and user support consultants are other external factors which may also influence EOU."

\subsubsection{Evaluasi kepercayaan (Trust) fasilitas billing}

Hasil wawancara yang lain menunjukkan bahwa kepercayaan narasumber terhadap keamanan dan manfaat yang akan diterima dari penggunaan MPN G2 dalam hal ini fasilitas pembuatan billing sekitar 94 persen positif. Keamanan dalam pembuatan billing dipercaya karena terdapat password dan username untuk masuk ke dalam aplikasi pembuatan billing tersebut. Jikaselama tidak ada masalah jaringan, sebagian narasumber percaya bahwa penggunaan fasilitas pembuatan billing dapat membantu mereka dalam melakukan pembayaran MPN G2.

\subsubsection{Evaluasi sikap (Attitude) fasilitas billing}

Pada model integrasi Trust-TAM-TPB yang dijelaskan oleh $\mathrm{Wu}$ dan Chen (2005), attitude terhadap sistem ditentukan bersama-sama oleh kegunaan (Perceived usefulness), kemudahan penggunaan (Perceived ease of use), dan kepercayaan terhadap sistem (Trust). Ketika berbicara terkait attitude terhadap MPN G2, dalam hal ini penggunaan fasilitas pembuatan billing, persepsi kemudahan (Perceived ease of use) dan persepsi kegunaan (Perceived usefulness) merupakan faktor kunci yang perlu ditingkatkan. Hal tersebut dikarenakan adanya kekurangan dari sistem tersebut yang dapat mengikis sisi positif dari kedua faktor tersebut. Terkikisnya persepsi positif pada dua faktor tersebut dapat mengurangi sikap positif user terhadap penggunaan sistem MPN G2 secara keseluruhan. Sedangkan Trust kepada sistem MPN G2 tidak terlalu dipermasalahkan oleh user, karena sebagian besar percaya dengan keamanan dan manfaat yang diterima dari MPN G2.

\subsubsection{Evaluasi Perceived behavioral control dan} Subjective Norm fasilitas billing

Respons narasumber cenderung positif terkait perceived behavioral control dan subjective norm terhadap fasilitas billing ketika kepercayaan mereka terhadap billing juga tinggi. Perceived behavioral control terhadap penggunaan sistem MPN G2 dalam hal ini pembuatan billing, tidak menjadi permasalahan bagi para narasumber dan sebagian besar memberikan respon yang positif. Pada dasarnya mereka tidak ada permasalahan pada kemampuan dan fasilitas untuk menggunakan MPN G2 khususnya dalam pembuatan billing. Mereka mampu untuk menggunakan sistem yang berbasis online dan fasilitas komputer dan jaringan internet yang tersedia. Semuanya masih dalam kendali mereka. Pada penggunaan MPN G2, khususnya pembuatan billing, sebagian besar narasumber tidak terlalu terpengaruh oleh norma subjektif yang berlaku di masyarakat. Mereka merasa penggunaan MPN G2 khususnya penggunaan fasilitas pembuatan billing adalah kebutuhan sehingga dalam penggunaannya mereka tidak terlalu dipengaruhi oleh pihak lain.

4.1.6. Evaluasi penerimaan (Intention to Use) fasilitas billing

Dari uraian di atas dapat disimpulkan bahwa penerimaan terhadap sistem MPN G2 khususnya terhadap penggunaan fasilitas billing, faktor kunci yang perlu diperbaiki adalah persepsi kemudahan (Perceived ease of use) dan persepsi kegunaan (Perceived usefulness).

\subsubsection{Tindak lanjut evaluasi}

Key factor penerimaan fasilitas-fasilitas billing tersebut seharusnya dapat diantisipasi oleh pembuat sistem baik business owner maupun biller 
MPN G2. Hal ini dimaksudkan agar penerimaan masyarakat akan penggunaan sistem MPN G2 dapat dimaksimalkan.Dari beberapa saran narasumber tersebut, maka perbaikan dalam sistem billing dapat dilakukan agar penerimaan user terhadap fasilitas billing meningkat. Perbaikan tersebut meliputi:

a. Perbaikan sistem billing, antara lain:

1) perbaikan jaringan terutama pada saat-saat transaksi sedang naik;

2) penambahan jumlah server;

3) perbaikan komunikasi data antara sistem perbankan dengan sistem MPN G2, sehingga ketidakcocokan data dapat dihindari;

4) khusus untuk fasilitas billing untuk pajak impor barang disediakan modul untuk melakukan proses rekam, ubah, dan hapus (RUH) data billing yang salah input.

5) perbaikan fitur untuk pemberian keterangan pembayaran;

6) penambahan menu untuk melakukan monitoring pada fasilitas billing pajak;

7) perbaikan tampilan dan cara menampilkan data untuk melakukan monitor billing pada fasilitas billing penerimaan bukan pajak; dan

8) penambahan menu petunjuk penggunaan atau halaman pertanyaan dan jawaban (A\&Q) terkait penggunaan fasilitas billing.

b. Peningkatan pengetahuan masyarakat mengenai fasilitas billing, antara lain:

1) pelaksanaan sosialisasi tentang penggunaan billing sistem baik untuk user yang menggunakan MPN G2 untuk pembayaran pajak, bea cukai, maupun penerimaan bukan pajak;

2) pembuatan iklan masyarakat tentang penggunaan fasilitas billing kepada masyarakat; dan

3) penyebaran pamflet atau jenis selebaran lainnya kepada masyarakat tentang penggunaan MPN G2 dalam hal ini penggunaan fasilitas billing.

\subsection{Evaluasi Fasilitas $E$-banking}

4.2.1.Evaluasi persepsi kegunaan (Perceived usefulness) fasilitas billing

Terlepas dari kegunaannya dalam memberikan fleksibilitas waktu dan tempat pembayaran, beberapa narasumber memberikan persepsi yang negatif akan kegunaan (PU) sistem $e$ banking dalam rangka pembayaran pajak, bea cukai, dan penerimaan bukan pajak. Kondisi itu membuktikan bahwa penggunaan fasilitas $e$ banking dirasa kurang dapat meningkatkan kinerja user dalam melakukan pembayaran pajak, bea cukai, maupun penerimaan bukan pajak. Hal tersebut dikarenakan oleh beberapa hal, yaitu: a. Masalah ritme kerja yang selama ini sudah terbiasa menggunakan uang tunai atau cek daripada menggunakan e-banking.

Sekitar 70 persen narasumber yang diwawancarai mengaku sudah memiliki sistem pembayaran yang sudah dilakukan sejak lama. Sistem pembayaran yang biasa mereka pakai adalah sistem persetujuan berjenjang dengan menggunakan uang tunai atau menggunakan cek. Penggunaan kanal e-banking membuat mereka merasa kesulitan karena mereka tidak terbiasa menggunakannya dan sistem persetujuan berjenjang mereka akan sulit untuk dilakukan. Hal tersebut membuat narasumber berpikir bahwa penggunaan e-banking tidak akan memberi manfaat bagi mereka jika dibandingkan tetap menggunakan kanal pembayaran melalui teller bank. Alsamday dkk (2013) mengatakan bahwa:

Bank's customers prefer to perform their transaction with banks by using offline services, therefore, this habit is preventing customer from using mobile banking services. Consequently, we suggest that there is a negative relationship between customer's habit and their perceived usefulness of mobile banking.

b. Adanya batas limit transaksi harian walaupun itu untuk pembayaran pajak, bea cukai, dan penerimaan bukan pajak sehingga mereka merasa kesulitan dan harus berkali-kali melakukan transaksi.

Kemudahan penggunaan e-banking saja tidak akan cukup untuk memberikan manfaat kepada user. Penggunaan beberapa produk e-banking yang terbatas pada limit transaksi harian membuat pembayaran penerimaan negara menjadi tidak efisien untuk pembayaran pajak dengan jumlah transaksi yang banyak atau jumlah yang besar. Ketidakefisienan tersebut karena untuk transaksi penerimaan yang besar, narasumber memerlukan beberapa produk $e$ banking yang berbeda karena keterbatasan limit transaksi harian atau apabila tidak terdapat lebih dari satu produk e-banking, maka narasumber terpaksa menunggu keesokan harinya untuk melakukan pembayaran. Hal tersebut pastinya membuat proses pembayaran menjadi lebih lama dari yang seharusnya. Sekitar 9 persen narasumber yang membayar pajak impor barang dengan menggunakan $e$ banking mengeluhkan kejadian tersebut.

Maditinos dkk (2013) mengatakan bahwa:

Hence, it can be argued that individuals' decisions on whether to use the service mainly depend on the perceived benefit accruing from its usage, as for example saving time and making transactions easier, compared to visiting a bank branch. 
4.2.2.Evaluasi persepsi kemudahan (Perceived ease of use) fasilitas billing

Dari hasil wawancara yang telah dilakukan, sekitar 60 persen narasumber memberikan respons yang positif terhadap kemudahan penggunaan MPN G2 khususnya dalam penggunaan e-banking. Dalam penggunaan sehari-hari mereka sebagian besar sudah terbiasa menggunakan fasilitas e-banking baik ATM, mobilebanking, maupun internetbanking untuk keperluan pribadi. Tidak ada kesulitan dalam menggunakan e-banking. Akan tetapi beberapa narasumber sisanya (sekitar 40 persen) mengaku kesulitan untuk menggunakan layanan e-banking. Kesulitan tersebut diakibatkan oleh:

a. Penggunaan kanal pembayaran teller bank dianggap lebih mudah daripada menggunakan kanal e-banking.

Narasumber berpendapat bahwa penggunaan kanal pembayaran teller bank dianggap lebih mudah daripada menggunakan kanal e-banking karena mereka hanya tinggal membawa nomor billing ke bank dan mereka tidak perlu mengisi form lagi di sistem e-banking yang menurut mereka rumit. Pembayaran penerimaan negara melalui e-banking di setiap bank berbeda. Kurangnya pengenalan dan petunjuk tentang pembayaran melalui e-banking membuat narasumber merasa kesulitan walaupun pada dasarnya prosesnya cukup mudah dan tidak memakan waktu yang lama.

Alsamday dkk (2013) mengatakan bahwa "Mobile banking systems must be both easy to learn and easy to use in order to prevent the using problems of mobile banking system."

b. Pendaftaran e-banking yang membutuhkan biaya dan usaha lebih, terlebih lagi untuk level kantor atau perusahaan yang prosesnya cukup rumit.

Pendaftaran e-banking memang cukup rumit dan memerlukan persyaratan yang cukup banyak, terlebih untuk level kantor atau pun perusahaan. Hal ini dikarenakan pihak perbankan ingin menjamin keamanan dari para nasabahnya. Selain itu kurangnya sosialisasi mengenai tata cara pendaftaran $e$-banking juga membuat masyarakat enggan untuk beralih menggunakan $e$-banking karena merasa proses pendaftaran yang sulit.

Jahangir dan Begum (2007) mengatakan bahwa "Researchers argued that perceived ease of use is the extent to which a person accepts as true that using an exacting method would be at no cost to that individual."

c. Kaleem \& Ahmad dalam (Kertiyasa, 2014) berpendapat bahwa "stated that e-banking was a means to minimalize discomfort, reduce transaction cost and safe time."

d. Adanya biaya tambahan yang dibebankan pada setiap transaksi menggunakan fasilitas $e$ banking.
Pada dasarnya seluruh transaksi penerimaan negara yang melalui bank persepsi tidak dikenakan biaya, baik dengan menggunakan teller maupun dengan menggunakan fasilitas $e$ banking. Bank/pos persepsi dilarang untuk menarik biaya dari masyarakat atas penerimaan negara yang dibayarkannya sesuai yang tercantum pada Peraturan Menteri Keuangan Nomor PMK-32/PMK.05/2014 pasal 18 ayat 4. Biaya mungkin akan muncul ketika produk e-banking suatu bank digunakan pada mesin milik bank lain atau penggunaan token yang berbayar. Pemahaman yang kurang akan penggunaan fasilitas e-banking khususnya dalam pembayaran penerimaan negara membuat narasumber merasa bahwa penggunaan e-banking membutuhkan biaya tambahan dibandingkan dengan menggunakan teller bank.

Jahangir dan Begum (2007) mengatakan bahwa "Researchers argued that perceived ease of use is the extent to which a person accepts as true that using an exacting method would be at no cost to that individual."

e. Anggapan user bahwa mereka akan kesulitan melakukan perbaikan apabila terjadi kesalahan. Pada dasarnya proses perbaikan atas transaksi penerimaan negara yang dibayarkan melalui teller bank maupun $e$-banking sama. Keduanya berpedoman pada Peraturan Menteri Keuangan Nomor PMK-32/PMK.05/2014 pasal 37 sampai dengan pasal 39. Akan tetapi biasanya narasumber yang menggunakan e-banking diminta untuk melakukan konfirmasi lagi ke pihak perbankan terkait bukti elektronik yang sudah mereka dapatkan sebagai salah satu lampiran dalam permintaan koreksi data.

Alsamday dkk (2013) mengatakan bahwa "Mobile banking systems must be both easy to learn and easy to use in order to prevent the using problems of mobile banking system."

4.2.3.Evaluasi kepercayaan (Trust) fasilitas billing

Kepercayaan narasumber terhadap keamanan dan manfaat yang akan diterima dari penggunaan $e$ banking dalam rangka pembayaran pajak, bea cukai, dan penerimaan bukan pajak cenderung negatif (lebih dari 50 persen dari keseluruhan narasumber yang diwawancarai). Leiva dkk (2016) mengatakan bahwa "The consumer will therefore be affected by a sense of insecurity and concern about the privacy and control of his or her personal information. Generation of Trust can compensate this concern about security and privacy." Selain itu Leiva dkk (2016) juga berpendapat bahwa "Trust reduces the need to understand, control and monitor thesituation, facilitating the use of the tool for the user without much effort." Ketidakpercayaan akan fasilitas e-banking disebabkan oleh beberapa hal antara lain:

a. keamanan dalam pembayaran dengan menggunakan e-banking dalam melakukan 
pembayaran pajak, bea cukai, dan penerimaan bukan pajak masih diragukan;

b. penggunaan e-banking rawan dengan penyelewengan; dan

c. kredibilitas tanda terima atau bukti pembayaran yang dihasilkan oleh fasilitas $e$ banking masih tidak dipercaya karena tidak ada tanda resmi atau stempel basah dari bank.

Ketidakpercayaan yang terjadi terjadi karena narasumber tidak mendapat informasi yang lengkap dari pemerintah maupun pihak perbankan bahwa penggunaan bukti dari fasilitas e-banking aman dan dapat digunakan selayaknya bukti yang didapatkan dari teller. Rendahnya penggunaan fasilitas e-banking oleh user mengindikasikan bahwa user belum menerima dan mengakui bahwa fasilitas e-banking dalam sistem MPN G2 sebagai sistem yang tepercaya dalam pengertian masih diragukan akan manfaatnya yang akan diterima dalam melakukan pembayaran pajak, bea cukai, dan penerimaan bukan pajak.

\subsubsection{Evaluasi sikap (Attitude) fasilitas billing}

Pada model integrasi Trust-TAM-TPB yang dijelaskan oleh $\mathrm{Wu}$ dan Chen (2005), Attitude terhadap sistem ditentukan bersama-sama oleh kegunaan (Perceived usefulness), kemudahan penggunaan (Perceived ease of use), dan kepercayaan terhadap sistem (Trust). Ketika berhubungan dengan Attitude terhadap MPN G2, dalam hal ini penggunaan fasilitas pembayaran dengan menggunakan e-banking, Trust, persepsi kemudahan (Perceived ease of use), dan persepsi kegunaan (Perceived usefulness) merupakan faktor kunci dalam mempengaruhi Attitude terhadap sistem MPN G2. Attitude yang ditunjukkan oleh sebagian besar narasumber adalah mereka tidak terlalu senang dengan penggunaan fasilitas $e$ banking dalam pembayaran penerimaan negara. Perasaan tidak senang tersebut diakibatkan oleh keraguan narasumber akan manfaat, kemudahan, dan kepercayaan narasumber akan fasilitas $e$ banking.

4.2.5.Evaluasi Perceived behavioral control dan Subjective norm fasilitas billing

Respons narasumber cenderung negatif terkait Perceived behavioral control dan Subjective norm terhadap fasilitas e-banking ketika kepercayaan mereka terhadap e-banking juga rendah. Walaupun secara kemampuan individu narasumber merasa bahwa mampu untuk menggunakan fasilitas $e$-banking, akan tetapi tidak tersedianya fasilitas e-banking disebabkan oleh faktor ketidakpercayaan terhadap keamanan dan manfaat yang akan diterima apabila menggunakan fasilitas $e$-banking tersebut, menyebabkan adanya fasilitas $e$-banking dirasa tidak diperlukan karena memang tidak akan digunakan dalam rangka pembayaran pajak, bea cukai, maupun penerimaan bukan pajak. Begitu pula dengan Subjective norm di mana respons negatif tersebut terjadi karena dalam penggunaan e-banking, mereka cenderung tidak dianjurkan untuk menggunakannya terutama oleh pimpinan mereka. Pimpinan tersebut tidak menganjurkan untuk menggunakan fasilitas $e$ banking karena mereka masih belum percaya akan keamanan dan manfaat yang akan diterima.

4.2.6. Evaluasi penerimaan (Intention to Use) fasilitas e-banking

Dari uraian di atas dapat disimpulkan bahwa penerimaan terhadap sistem MPN G2 khususnya terhadap penggunaan fasilitas e-banking, faktor kunci yang perlu ditingkatkan adalah persepsi kemudahan (Perceived ease of use), persepsi kegunaan (Perceived usefulness), dan Trust.

\subsubsection{Tindak lanjut evaluasi}

Dari uraian di atas, maka diperlukan perbaikan dalam fasilitas e-banking. Perbaikan tersebut meliputi:

a. Perbaikan sistem e-banking dengan jalan:

1) melakukan perjanjian kepada perbankan tentang batasan penggunaan e-banking dalam rangka pembayaran pajak; dan

2) mendorong kepada perbankan untuk mempermudah pembuatan fasilitas $e$ banking khususnya kepada perusahaan atau instansi tertentu.

b. Peningkatan pengetahuan dan kepercayaan masyarakat mengenai fasilitas $e$-banking dalam pembayaran pajak, bea cukai, dan penerimaan bukan pajak, antara lain dengan:

1) menggandeng pihak perbankan untuk ikut melakukan sosialisasi tentang penggunaan $e$-banking untuk pembayaran pajak, bukan pajak, maupun penerimaan bukan pajak;

2) membuat iklan masyarakat tentang keamanan dan manfaat penggunaan fasilitas e-banking khususnya untuk pembayaran pajak, bukan pajak, maupun penerimaan bukan pajak kepada masyarakat; dan

3) menyebarkan pamflet atau jenis selebaran lainnya kepada masyarakat tentang keuntungan, keamanan, dan prosedur pembayaran pajak, bukan pajak, maupun penerimaan bukan pajak.

\section{KESIMPULAN DAN SARAN}

Dari hasil analisis dan evaluasiterdapat beberapa hal yang dapat disimpulkan yaitu:

a. Penerimaan narasumber terhadap MPN G2 sebagian besar adalah positif. Perasaan positif tersebut didapatkan karena penggunaan MPN G2 memberikan keuntungan kepada narasumber dan mempermudah narasumber dalam melakukan pembuatan billing. Narasumber tidak perlu lagi membuat surat 
setoran secara manual, sehingga baik waktu, tenaga, dan biaya dapat dihemat. Walaupun begitu narasumber mendapatkan beberapa pengalaman negatif terkait penggunaan fasilitas billing yang jika tidak ditangani akan berpotensi merugikan narasumber.

Di sisi lain, penggunaan $e$-banking sebagai salah satu keunggulan dari MPN G2 kurang mendapat respons positif dari sebagian besar narasumber. Kanal pembayaran konvensional yaitu melalui teller bank lebih dipilih dalam rangka pembayaran pajak/bea cukai/penerimaan negara bukan pajak. Narasumber merasa bahwa penggunaan fasilitas e-banking dalam rangka pembayaran pajak, bea cukai, dan penerimaan bukan pajak berpotensi memberikan masalah dan kerugian kepada narasumber. Masalah tersebut terkait dengan kepercayaan narasumber tentang kemudahan, manfaat, dan keamanan yang akan mereka dapatkan apabila menggunakan fasilitas $e$-banking tersebut.

b. Faktor-faktor kunci yang perlu ditingkatkan dalam penerimaan dan penggunaan sistem MPN G2 dalam proses pembayaran pajak, bea cukai, dan penerimaan negara bukan pajak berbeda antara fasilitas pembuatan billing dengan fasilitas e-banking. Pada penggunaan fasilitas pembuatan billing faktor utama penerimaan sistem yang perlu diperbaiki yaitu: persepsi kemudahan (Perceived ease of use), dan persepsi kegunaan (Perceived usefulness). Sedangkan pada penggunaan fasilitas $e$-banking faktor utama yang perlu diperbaiki adalah persepsi kegunaan (Perceived usefulness), persepsi kemudahan (Perceived ease of use), dan kepercayaan (Trust).

c. Kendala yang dialami oleh narasumber dalam penggunaan sistem MPN G2 dapat dibagi menjadi dua kategori yaitu kendala dalam menggunakan fasilitas pembuatan billing dan kendala dalam penggunaan fasilitas $e$-banking. Kendala yang dialami narasumber dalam penggunaan fasilitas pembuatan billing antara lain:

1) Proses pembuatan billing yang membutuhkan waktu yang lama pada saat jaringan atau serverbilling mengalami gangguan, padahal narasumber membutuhkan proses yang cepat.

2) Proses perbaikan yang rumit dan membutuhkan waktu yang lama atas billing yang sudah terlanjur diterbitkan khususnya untuk pembuatan billing untuk pajak impor barang.

3) Perbedaan data antara server MPN G2 dengan data pembayaran di bank sehingga user yang statusnya sudah melakukan pembayaran, tercatat belum melakukan pembayaran di sistem MPN G2.

4) Kesulitan untuk mengakses atau masuk ke halaman pembuatan billing dan kalaupun sudah masuk, mereka tidak akan bisa membuat billing karena seringkali log out sendiri, sehingga berkali-kali user harus log in ulang.

5) Kesulitan untuk melakukan monitoring billing yang sudah dibuat dan dibayar karena desain menu monitoring yang susah untuk digunakan.

6) Keterbatasan untuk memberikan keterangan pembayaran pada billing yang dibuat.

7) Kesulitan untuk menggunakan aplikasi bagi pengguna yang baru karena masih minimnya petunjuk penggunaan aplikasi billing terutama petunjuk yang melekat pada aplikasi tersebut. Hal tersebut membuat narasumber kesulitan untuk mengetahui fungsi dari setiap menu yang disediakan dan bagaimana langkahlangkah untuk menggunakan aplikasi tersebut.

Kendala yang dialami user terkait penggunaan fasilitas e-banking dalam melakukan pembayaran pajak, bea cukai, dan penerimaan negara bukan pajak antara lain:

1) Penggunaan kanal pembayaran e-banking dirasa kurang sesuai dengan ritme kerja pembayaran mereka selama ini yang masih menggunakan cek dan uang tunai.

2) Pendaftaran $e$-banking yang membutuhkan biaya dan usaha lebih, terlebih lagi untuk level kantor atau perusahaan yang cukup rumit.

3) Penambahan biaya yang dikeluarkan terkait pembayaran pajak, bea cukai, penerimaan negara bukan pajak saat menggunakan e-banking.

4) Penggunaan e-banking yang tidak efisien karena adanya limit penggunaan saat melakukan pembayaran.

5) Penggunaan bukti penerimaan negara yang dihasilkan oleh fasilitas e-banking kurang dapat diterima oleh narasumber jika dibandingkan dengan bukti yang dihasilkan langsung dari teller bank.

6) Penggunaan e-banking dalam melakukan pembayaran pajak, bea cukai, dan penerimaan negara bukan pajak masih diragukan keamanannya.

7) Penggunaan e-banking dirasakan rawan penyelewengan.

d. Beberapa hal yang perlu diperbaiki dalam meningkatkan penerimaan pengguna (UserAcceptance) terhadap sistem MPN G2 secara keseluruhan, antara lain: 
1) Untuk meningkatkan penerimaan fasilitas pembuatan billing diperlukan perbaikan terkait persepsi kemudahan (Perceived ease of use) dan persepsi kegunaan (Perceived usefulness) dengan jalan perbaikan sistem billing dan sosialisasi.

2) Untuk meningkatkan penerimaan dan penggunaan fasilitas pembayaran menggunakan fasilitas e-banking perlu untuk menaikkan kepercayaan (Trust) user, persepsi kemudahan (Perceived ease of use) dan persepsi kegunaan (Perceived usefulness) terhadap penggunaan $e$-banking melalui perbaikan sistem dan sosialisasi pemanfaatan e-banking dalam rangka pembayaran pajak, bea cukai, dan penerimaan negara bukan pajak.

Berdasarkan simpulan yang sudah dijabarkan di atas, penulis memberikan saran sebagai berikut:

a. Para biller sistem MPN G2 baik Direktorat Jenderal Pajak, Direktorat Jenderal Bea dan Cukai, maupun Direktorat Jenderal Anggaran perlu untuk memperbaiki kualitas jaringan dan server yang digunakan terkait pembuatan billing. Hal ini perlu dilakukan dalam rangka meningkatkan persepsi kemudahan (Perceived ease of use) dan persepsi kegunaan (Perceived usefulness) penggunaan fasilitas billing. Penguatan jaringan dapat dilakukan dengan penambahan bandwidth yang disesuaikan dengan jumlah pengguna aplikasi billing di seluruh Indonesia. Penguatan server dilakukan dengan peningkatan spesifikasi serverbilling dan penambahan jumlah server yang digunakan untuk mengelola fasilitas billing. Penambahan server dan bandwidth membutuhkan biaya yang cukup besar sehingga prosesnya pengadaannya dapat dilakukan secara bertahap pada masingmasing biller. Selain itu perlu juga kerja sama juga perlu dilakukan dengan unit eselon Ipengelola teknologi dan informasi yaitu Pusat Informasi dan Teknologi Keuangan Kementerian Keuangan.

b. Para biller pada sistem MPN G2 baik Direktorat Jenderal Pajak, Direktorat Jenderal Bea dan Cukai, maupun Direktorat Jenderal Anggaran perlu untuk memperbaiki kualitas aplikasi pembuatan billing. Hal ini perlu dilakukan dalam rangka meningkatkan persepsi kemudahan (Perceived ease of use) penggunaan fasilitas billing. Fungsi monitoring billing pada aplikasi pembuatan billing perlu untuk ditambahkan dan diperbaiki. Tampilan dan penggunaan menu monitoring billing perlu dibuat lebih userfriendly atau lebih mudah digunakan, sehingga tanpa melihat dokumen bukti pembayaran dan menginput bukti pembayaran, user dapat melihat histori keseluruhan billing secara otomatis, baik yang sudah dibuat, belum dibayar, dan sudah dibayar. Perbaikan di sisi pemberian keterangan pembayaran juga perlu dilakukan karena user membutuhkan fitur dimana mereka bisa menambahkan keterangan pembayaran yang lengkap. Selain itu perlu dibuat semacam menu tersendiri terkait tutorial atau cara penggunaan dan question and answer(Q\&A) aplikasi billing itu sendiri.

c. Direktorat Jenderal Perbendaharaan selaku pengelola sistem settlement MPN G2, perlu memperbaiki komunikasi data antara server MPN G2, server tagihan biller dan server dari perbankan sehingga perbedaan data dapat dihindari. Hal ini perlu dilakukan dalam rangka meningkatkan ketepatan dan keakuratan informasi yang dihasilkan fasilitas billing sehingga persepsi kegunaan (Perceived usefulness) penggunaan fasilitas billing juga akan meningkat.

d. Direktorat Jenderal Perbendaharaan selaku mediator antara biller, pihak perbankan, dan user dapat mendorong pihak perbankan untuk mempermudah proses pembuatan fasilitas $e$ banking kepada perusahaan atau instansi tertentu serta menambah limit pembayaran khusus untuk pembayaran pajak, bea cukai, dan penerimaan bukan pajak. Selain itu Direktorat Jenderal Perbendaharaan juga dapat mendorong pihak perbankan untuk menerapkan kebijakan batasan limit transaksi harian khususnya untuk transaksi pembayaran pajak/bea cukai/penerimaan negara bukan pajak. Hal ini perlu dilakukan dalam rangka meningkatkan persepsi kemudahan (Perceived ease of use) dan persepsi kegunaan (Perceived usefulness) penggunaan fasilitas e-banking. Persepsi kemudahan (Perceived ease of use) penggunaan fasilitas e-banking dapat meningkat seiring dengan meningkatkannya kemudahan pendaftaran dan administrasi $e$ banking. Persepsi kegunaan (Perceived usefulness) penggunaan fasilitas e-banking dapat meningkat juga seiring dengan semakin mudahnya penggunaan fasilitas e-banking untuk pembayaran pajak, bea cukai, dan penerimaan negara bukan pajak dengan ditingkatkannya limit penggunaan e-banking, sehingga user tidak merasa kerepotan jika membayar pajak, bea cukai, dan penerimaan negara bukan pajak dengan jumlah yang cukup besar.

e. Perlunya dilakukan sosialisasi tentang penggunaan MPN G2 kepada masyarakat baik pembuatan billing maupun pembayaran dengan menggunakan kanal e-banking. Hal ini perlu dilakukan dalam rangka meningkatkan persepsi kemudahan (Perceived ease of use), 
persepsi kegunaan (Perceived usefulness) dan kepercayaan (Trust) penggunaan fasilitas $e$ banking dan fasilitas billing. Sosialisasi terkait penggunaan fasilitas billing dapat membantu user yang baru menggunakan fasilitas billing menjadi lebih familiar akan penggunaan dan fitur-fitur yang ada di dalamnya, sehingga secara otomatis dapat meningkatkan persepsi kemudahan (Perceived ease of use) penggunaan fasilitas billing. Selama ini sosialisasi penggunaan fasilitas hanya dilakukan secara insidental dan terbatas, padahal pengguna fasilitas billing terus bertambah. Sosialisasi tentang penggunaan fasilitas e-banking sangat diperlukan terutama untuk membentuk kepercayaan (Trust) masyarakat akan keamanan dan kredibilitas fasilitas e-banking. Sosialisasi tentang penggunaan fasilitas $e$ banking dalam rangka pembayaran penerimaan negara masih jarang dilaksanakan sehingga hal ini menjadi kunci dalam meningkatkan penerimaan dan penggunaan fasilitas $e$ banking. Persepsi kemudahan (Perceived ease of use) penggunaan fasilitas e-banking juga dapat ditingkatkan seiring peningkatan pemahaman user terkait tata cara penggunaan fasilitas $e$ banking dalam melakukan pembayaran penerimaan negara. Selain itu pemahaman yang keliru terkait adanya biaya tambahan yang dikeluarkan terkait pembayaran penerimaan negara melalui kanal e-banking dapat diluruskan. Persepsi kegunaan (Perceived usefulness) fasilitas e-banking juga dapat ditingkatkan melalui pembentukan pemahaman bahwa fasilitas e-banking akan membuat pekerjaan user menjadi lebih cepat dan tepat.

f. Sosialisasi harus dilakukan oleh berbagai pihak baik Direktorat Jenderal Perbendaharaan melalui kantor vertikalnya untuk memberikan pemahaman kepada bendahara-bendahara pemerintah, Direktorat Jenderal Pajak melalui kantor vertikalnya untuk memberikan pemahaman kepada para wajib pajak, Direktorat Jenderal Bea Cukai untuk memberikan pemahaman kepada wajib bayar pajak, pabean, dan cukai, dan Direktorat Jenderal Anggaran untuk memberikan pemahaman kepada institusi yang berkaitan dengan pembayaran penerimaannegara bukan pajak. Sosialisasi ini dapat dilakukan tersendiri dengan menggandeng pihak perbankan atau disisipkan pada sosialisasi-sosialisasi yang lain.

g. Perlunya disebarkan iklan masyarakat terkait penggunaan MPN G2 baik fasilitas billing maupun penggunaan e-banking dalam melakukan pembayaran pajak, bea cukai, dan penerimaan bukan pajak melalui berbagai macam media iklan yang tersedia. Iklan diperlukan sebagai bentuk pemberitahuan kepada masyarakat umum yang tidak terjangkau dengan sosialisasi. Hal ini perlu dilakukan dalam rangka meningkatkan persepsi kemudahan (Perceived ease of use), persepsi kegunaan (Perceived usefulness) dan kepercayaan (Trust) penggunaan fasilitas ebanking dan fasilitas billing. Iklan baik melalui media elektronik maupun media cetak dapat menjadi sarana yang tepat, cepat, dan konsisten dalam memberikan pemahaman kepada masyarakat akan kemudahan, kegunaan, dan keamanan sistem MPN G2 baik fasilitas $e$ banking dan fasilitas billing dalam melakukan proses pembayaran penerimaan negara. Pembuatan iklan dapat dilakukan terpusat oleh Kementerian Keuangan melalui biro KLI Sekretariat Jenderal, maupun melalui eselon I lingkup Kementerian Keuangan yang terlibat.

\section{KETERBATASAN}

Keterbatasan pada penelitian ini adalah kesulitan untuk melakukan salah satu uji validitas yaitu dengan jalan memberchecking terhadap narasumber yang telah penulis wawancarai. Kesulitan tersebut disebabkan oleh keterbatasan waktu dan biaya untuk menemui secara langsung narasumber-narasumber yang jumlahnya cukup banyak. Salah satu solusi yang dilakukan adalah dengan mengirimkan hasil laporan akhir dari wawancara yang telah dilakukan proses coding kepada narasumber melalui email atau sarana yang lain kepada narasumber, kemudian meminta narasumber untuk menyampaikan kembali pendapatnya tentang hasil wawancara apakah sudah sesuai dengan maksud narasumber atau belum.

\section{PENGHARGAAN (ACKNOWLEDGEMENT)}

Penelitian ini dapat diselesaikan berkat bantuan dan dukungan dari berbagai pihak. Dalam kesempatan ini penulis ingin mengucapkan terima kasih khususnya kepada kepadaBapak Irwan Suliantoro, S.E., M.T.I. selaku dosen pembimbing materi.

\section{REFERENSI}

Ajzen, I. (1991). The theory of planned behavior. organizational behavior and human decision process 50, 179-211. Diakses 20 Oktober 2017 dari http://www.sciencedirect.com/science/ article/pii/074959789190020T

Alsamday, Mahmood Jasim dkk. (2013). The factors influencing customer usage of mobile banking services in jordan. International Journal of Business Management \& Research (IJBMR) Vol. 4, Issue 2, Apr 2014, 63-78. Diakses 19 
Desember 2017 dari http://www.zuj.edu.jo/ wp-content/staff-research/economic/ dr.saadyaseen/7.Pdf

Creswell, J.W. (2016). Research design: Pendekatan metode kualitatif, kuantitatif, dan campuranEdisi Ke-4. Yogyakarta: Pustaka Pelajar.

F.D. Davis, R. Bagozzi and PP. Warshaw.(1989).Useracceptance of computer technology: A comparison of two theoretical models, Manage. Sci., vol. 35, no8, pp. 9821003. Diakses 20 Oktober 2017 dari https://www.researchgate.net/profile/Richar d_Bagozzi/publication/248251146_User_Acce ptance_of_Computer_Technology_A_Comparis on_of_Two_Theoretical_Models/links/57c85fa 208ae9d640480e014.pdf

Fishbein, M. \& Ajzen, I. (1975). Belief, attitude, intention, and behavior: An introduction to theory and research. Addison-Wesley, Reading, MA.

Iskandar. (2017). Keterlambatan pelimpahan penerimaan negara pada sistem treasury single account (TSA): Analisis teknis dan yuridis. Jurnal Manajemen Keuangan Publik.Tangerang Selatan: Politeknik Keuangan Negara STAN.

Kertiyasa, Ni Nyoman dkk. (2014). The application of technology acceptance model on internet bankingusers in the city of Denpasar, 16(2), 93102. Diakses 19 Desember 2017 dari http://jurnalmanajemen.petra.ac.id/index .php/man/article/view/18917/18592

Kotler, Phillip. (2000). Marketing management edisi millenium. New Jersey: Prentice Hall.

Lee, Y., Kozar, K. \& Larsen, K. (2003). The technology acceptance model: Past, present, and future. Communications of the association for information systems, 12, pp.752-780. Diakses19 Desember 2017 dari http://aisel.aisnet.org/cgi/viewcontent.cgi?ar ticle $=3217 \&$ context $=$ cais

Leiva, Munoz F., dkk. (2016). Determinants of intention to use the mobile bankingapps: An extension of the classic TAM model. Spanish Journal of Marketing ESIC (2017) 21, 25-38. Diakses17 Desember 2017 dari http://www.sciencedirect.com/science/articl e/pii/S24 44969516300555

Liao, Z. \& Cheung, M.T. (2002). Internet-based ebanking and consumer attitudes: An empirical study. Information \& Management, 39, 283295. Diakses17 Desember 2017 dari http://www.scirp.org/(S(351jmbntvnsjt1aad
kposzje))/reference/ReferencesPapers.aspx? ReferenceID $=1966687$

Lin, J. C., \& Lu, H. (2000). Towards an understanding of the behavioral intention to use a web site.International Journal of Information Management, 20, 197-208. Diakses19 Desember 2017 dari https://www.sciencedirect.com/science/artic le/pii/S0268401200000050

Maditinos, Dimitrios. (2013). An examination of the critical factors affecting consumer acceptance of onlinebanking a focus on the dimensions of risk. Journal of Systems and Information Technology Vol. 15 No. 1, 2013 pp. 97-116. Diakses19 Desember 2017 dari http://abd.teikav.edu.gr/new_articles/041_ex amination.pdf

Moleong, Lexy J. (2014). Metodologi penelitian kualitatif edisi revisi. Bandung: PT Remaja Rosdakarya.

Syah, Muhibbin. (2005). Psikologi belajar. Jakarta: Raya Grafindo Perkasa.

Omar, Abdurrahman. (2016). Evaluation of electronic prescribing system, user acceptance perspective. Sweden. Diakses 21 Oktober 2017darihttp://www.diva-portal.se/smash/ get/diva2:941864/FULLTEXT01.pdf

Pavlou, P.A. (2003). Consumer acceptance of electronic commerce-integrating Trust and risk with the technology acceptance model. International Journal of Electronic Commerce 7 (3), 69-103. Diakses 21 Oktober 2017 dari https://www.jstor.org/stable/27751067

Peraturan Menteri Keuangan Nomor 32/PMK.05/2014 tentang Sistem Penerimaan Negara Secara Elektronik. Jakarta: Kementerian Keuangan.

Peraturan Direktur Jenderal Perbendaharaan Nomor PER-78/PB/2006 tanggal 27 Desember 2006 tentang Penatausahaan Penerimaan Negara Melalui Modul Penerimaan Negara. Jakarta: Direktorat Jenderal Perbendaharaan.

Renaud, K. \& Van Biljon, J. (2008). Predicting technology acceptance and adoption by the elderly. In Proceedings of the 2008 annual research conference of the South African Institute of Computer Scientists and Information Technologists on IT research in developing countries riding the wave of technology SAICSIT '08. ACM Press, pp. 210-219: New York, USA.

Robbins, Stephen P. (2003). Perilaku organisasi. Jakarta: PT Indeks Kelompok. 
Subkhani, Hidayat. (2016). Evaluasi terhadap penggunaan sistem billingonline DJBC dengan pendekatan technology acceptance model (studi kasus di KPU Bea dan Cukai Tipe A Tanjung Priok). Skripsi. Tidak dipublikasikan, PKN STAN.

Tankard, J.W. (2001). The Empirical approach to the study of media framing.

Undang-Undang Nomor 1 Tahun 2004 tentang Perbendaharaan Negara. Jakarta: Republik Indonesia.

Wu, In Long \& Chen, Jiang Liang. (2005). An extension of trust and TAM model with TPB in the initial adoption of on-line tax: An empirical study. Diakses21 Oktober 2017 dari http://www.sciencedirect.com/science/articl e/pii/S1071581905000376 